\title{
2 Active participation in the energy transition
}

\section{The challenges of European regulation}

\author{
Johannes Antoni and Michael Rodi
}

\section{Introduction}

The European Union (EU) has the political goal of becoming the global leader in energy production from renewable energy sources (RES), with an emphasis on five dimensions: "energy security, [an] internal energy market, energy efficiency, decarbonisation and inventions" (European Commission, 2019: 1). Western European countries in the Baltic Sea Region like Germany, Denmark and Sweden have established remuneration regimes to incentivise a rising share of RES, leading to a rapid increase of renewable energy (RE) in their respective power mixes. In eastern Baltic states like Poland and Latvia, on the other hand, RES production appears to have stagnated at low levels due to the later promotion of RE in these countries. As a result, eastern Baltic states remain highly dependent on coal as a primary source of energy. There is thus significant disparity between the efforts made by countries of the Baltic Sea Region to meet the binding EU target of at least 32\% RE in gross final energy consumption by 2030 (under Art. 3.1 Directive (EU) 2018/2001 Renewable Energy Directive or RED II) or even to become the first climate-neutral continent.

An increasing number of RE generators, like offshore wind farms and photovoltaic (PV) systems, is needed to reach RE targets and make the energy transition successful across the EU. However, RES projects in Poland, for example, have been hampered by the stagnation of the wind energy sector (Surwillo, in this book). In addition, many Baltic States still lack an appropriate financial and legal framework to empower ordinary citizens (Pons-Sere de Brauwer and Cohen, in this book), incentivise the growing societal interest in RES and democratise access to energy.

The required modernisation of the energy and heat supply in several Baltic States presents unique opportunities to expand RES in these states (Pietrzykowski, Rembarz and Cenian; Laakso and Lukkarinen, both in this book). The increasing number of RES generators will place a growing burden on electricity grids, which can be exacerbated by new consumers such as electric vehicles, heat pumps and electric storage heaters without good regulation.

A general challenge for the Baltic Sea Region - as for all EU Member States - is to enhance awareness about the need for not only climate change mitigation, 
but also for acceptance of RES projects (Kojo, et al., in this book) and even active participation in RES production (Magnusson; Komendantova, Nkoana and Neumueller, both in this book). It will be easier to mobilise people for a transition to RES if there is more honest and open-ended political conversation and if more information is made available about RES projects and the opportunity for citizens to participate in comprehensive visions.

The active participation of consumers could have a meaningful impact on the energy transition in the EU. The RED II has already laid out a new foundation for increasing RE. It is now the responsibility of the EU Member States to act on this foundation by changing the structure of their energy production and consumption accordingly. Generally, Member States need more flexibility in demand without leaving their citizens behind. Citizens, as consumers, are regarded as having a more central role in the future energy system, as they can present a potential bottleneck: a lack of social acceptance demands a change in policymaking (Olsen, in this book). A conceptual framework based on the agents of change theory and energy justice can therefore provide a useful tool for creating acceptance by designing socially innovative business models for prosumers (Standal and Feenstra, in this book).

\section{Materials and methods}

This chapter examines the requirements and scope for implementing the EU law and policy framework, particularly in the Baltic EU States, to activate their citizens for the energy transition. First, the current state of affairs regarding the active participation of people in the EU energy transition is described based on codifications, legal articles and studies. The existing conceptual framework in European law for the active participation of consumers in the energy transition is then analysed and compared with relevant Polish and German law based on legal and other official state documents, because these two countries are the biggest in the region and have the highest $\mathrm{CO}_{2}$ emissions. The chapter concludes with a summary of further steps that the EU Member States must take to implement the European framework.

\section{Political and legal discourse on active participation of people in the energy transition}

It is first necessary to define what is meant by the "active role of people within the political and legal discourse on energy transition." The energy transition (German: Energiewende) is a mega-project that intertwines technological and political perspectives; it is therefore a political, or at least politically connoted, term (Dernbach, 2015). In this context, acceptance is a central factor in the success of the energy transition. Acceptance is needed from everyone who is affected by the transition; this includes not only those on the energy production side, but also electricity consumers. One way to generate acceptance is to actively involve people in the processes of production and consumption. This invokes the 
discourse about the "activation of people," since there are various methods and levels of participation.

At the first level of active participation, prosumers can "flexibilise" their electricity consumption. Flexible electricity consumption can contribute to the success of the energy transformation (IEA, 2019). "Flexible consumption" means using electricity when it is available in excess and reducing consumption when there is a shortage of production. Since the amount of electricity fed into the grid from RES will increasingly fluctuate due to weather conditions, e.g., wind, a flexible response is needed, such as the capacity to switch a heat pump on or off or recharge an electric vehicle. The necessary technical requirements for such responses are already in place. Final consumers are increasingly able to help maintain the stability of the entire electricity system and thus contribute to the security of supply. Nevertheless, the full potential of flexibility offered by household customers has not yet been fully utilised due to the lack of real incentives for consumers to offer such flexibility (Leal-Arcas et al., 2018). There is not an appropriate price signal or adequate coordination between consumers in the context of grid operation. There are, however, economic benefits to the activation of neighbours and communities and even to the organisation of these entities into cooperatives as a potent means of securing flexibility, e.g., through a new distribution system in which prosumers are encouraged by different balancing premiums to balance their electricity in a local community (Cai et al., 2016).

A consumer who offers flexibility is not automatically an active participant. Flexible consumption can be provided without active participation, e.g., through the implementation of an appropriate electricity tariff or the installation of interruptible or controllable consumer technologies (mainly night storage heaters and electric heat pumps) for space heating. In the future, the charging processes of electric vehicles will also become relevant in this context. For this kind of flexible electricity consumption, a third party is typically tasked with ensuring that the flexibility is provided without burdening the consumer. Ideally, the consumer will not even notice this kind of management in their daily lives. Apart from the conscious decision on an appropriate tariff, there is no active participation of the consumer; this is therefore generally not understood to be active consumer participation. However, this flexibility service can play a crucial part in the energy transition. The provision of this service by companies as aggregators or new energy actors (Leal-Arcas et al., 2018) is more comparable with provision by commercial or industrial consumers. These are already regarded as flexible consumers who often actively reduce their electricity demand and thus contribute to balancing supply and demand in the overall electricity system (Bons et al., 2020). Commercial consumers are excluded from the following analysis, as the focus is on private actors.

Consumers reach the second level of active participation by self-producing electricity. This is where the consumer begins to function as a "prosumer" (Bundesnetzagentur, 2016). "Prosumer" is an umbrella term that refers to a simultaneous role as producer and consumer; its use is not limited to electricityrelated topics. Whether electricity prosumers operate as a private household or 


\section{Johannes Antoni and Michael Rodi}

as an energy community, their role falls somewhere between that of a consumer and that of an entrepreneur (Roberts et al., 2014; Leal-Arcas et al., 2018). They are commonly understood to be self-generating electricity providers who consume the electricity that they generate themselves (e.g., from a PV system) and/ or feed this electricity into the grid. If there is not enough self-generated electricity available, prosumers can also obtain electricity from the public supply network. At least in Germany, the term is often used for household customers, though often without further definition (Wübbels, 2015; Bundesregierung, 2016: 1/62/107/109; Milovanović, 2019) or without a precise distinction (Pielow, 2010; Müller-Kirchenbauer and Leprich, 2013; Schäfer-Stradowsky and Timmermann, 2018), in contrast to what is proposed above.

The European Parliament Research Service expanded the definition of prosumer to include more than just households. It distinguished four types of actors: residential prosumers (who produce electricity at home on their rooftops), citizen-led energy cooperatives and commercial and public prosumers (EPRS, 2016). European law, on the other hand, reflects a narrower understanding of prosumers, defining them as "renewables self-consumers." More precisely, Art. 21 RED II refers to individuals and communities that are entitled to generate, consume, store or sell electricity from RES as "prosumers." The present chapter focuses on private households and citizen-led energy communities who act as prosumers.

In addition to distinguishing between types of prosumer, one can also differentiate specific processes of participation. Prosumer activities are not limited to self-producing and self-consuming electricity. The German Federal Ministry for Economic Affairs and Energy (BMWi) interprets private prosumers more broadly, stating that "even without a solar system on the rooftop, households can be prosumers in the future. Because a flexible approach to electricity consumption can also contribute to the success of the energy transition" (BMWi -energiewende.de, 2016). Deviating from this interpretation, the present chapter defines a prosumer as a person who self-produces electricity - provided that electricity production is not the main business activity - without an obligation to self-consume. A private person can therefore participate in active prosumption at different sublevels, which can also be combined: the self-production of electricity, the self-consumption of electricity and the provision of potential flexibility in electricity consumption. The "provision of flexibility" can involve the use of batteries for electricity storage or even direct participation in demand response (Roberts, 2016).

There is also a third level of active participation: the sharing of energy as part of a "citizen energy community" (Art. 2(11) Directive (EU) 2019/944 Electricity Market Directive or EMD) - not to be confused with the "Energy Community," an international organisation established between the EU and a number of third countries to extend the EU internal energy market to Southeast Europe and beyond. ${ }^{1}$ This level of participation can even include the sale of self-produced electricity; in this case, the prosumer becomes an energy trader or supplier. 
In conclusion, active participation in the energy transition can take place at three levels: provision of flexibility in consumption, operation as an electricity producer and prosumer and participation in a citizen energy community that may act as an electricity trader or supplier.

\section{European framework for the active participation of consumers}

On 30 November 2016, the European Commission presented legislative proposals as part of the Clean Energy for All Europeans package. ${ }^{2}$ These proposals were developed to implement the conclusions of the European Council of October 2014 on the framework for climate and energy policy until 2030 (European Council, 2014). A significant part of the reform covered the recasting of legal acts adopted within the framework of the Third Internal Energy Market Package of 2009, which addressed the internal electricity market and promotion of RES. The new regulation on the internal market in electricity (Regulation (EU) 2019/943 - Electricity Market Regulation or EMR) has been directly applicable in the Member States since 1 January 2020. The recast Directive on the internal electricity market (Directive (EU) 2019/944 - Electricity Market Directive or EMD) was to be implemented by the Member States by 31 December 2020 at the latest (Art. 71(1) EMD). The RED II must be implemented by the national legislatures by 30 June 2021 (Art. 36(1) RED II).

Digitalisation, technological progress in grid management and the generation of RES have unlocked (new) opportunities, including the active participation of consumers, that allow for an improved local coordination of load and generation and will thus help to avoid regional grid bottlenecks. For this reason, "consumers have an essential role to play in achieving the flexibility necessary to adapt the electricity system to variable and distributed renewable electricity generation," as stated in recital 10 EMD. The EMD aims to strengthen the participation of various players in the electricity market and thereby reduce obstacles to citizen-supported supply concepts. Art. 15 EMD regulates the rights of "active" customers, which, according to the definition in Art. 2(8) EMD, also include prosumers. According to these provisions, active customers may not be subject to disproportionate or discriminatory technical and administrative requirements, procedures, levies or charges, or to non-costoriented network charges. In accordance with these European legal requirements, it is likely that any equation of prosumers with energy supply companies is contrary to European law, since these companies are subject to disproportionate administrative requirements. Consequently, the legislature may need to modify national regulations in some cases in order to ensure compatibility with European standards.

It is equally significant that, for the first time at EU level, the RED II defines the rights of self-consumers in the field of renewable electricity (Art. 21 RED II) and the rights of renewable energy communities (Art. 22 RED II). It specifies certain framework conditions with regard to financial burdens in the form of taxes and levies and obliges the Member States to create an enabling framework (Pause 


\section{Johannes Antoni and Michael Rodi}

and Kahles, 2019) for these actors in national law by 1 July 2021 (Art. 36(1) RED II).

\section{Flexibility in consumption}

The EU considers healthy competition in retail markets to be essential to ensure a market-driven deployment of innovative new services that can address the changing needs and abilities of consumers and increase electricity system flexibility to meet EU RES targets. Of particular importance is the inclusion of a completely new area of regulation in the EMD, which requires the activation of consumers, the introduction of new forms of participation and a greater focus on the flexibility of consumption and production. To this end, active customers, prosumers, citizen energy communities and aggregators, as decentralised actors, have been mentioned for the first time at EU level and recognised as having dedicated rights and obligations.

Art. 3(1) EMD, titled "Competitive, consumer-centred, flexible and nondiscriminatory electricity markets" obligates Member States to comply with the Directive by means of a horizontal clause. They must ensure that their national legislation does not unnecessarily impede cross-border electricity trade or consumer participation, including demand management. This also applies to investments, especially in variable and flexible energy generation, energy storage, the expansion of electromobility or new interconnectors between Member States.

A direct incentive for more flexible consumption is provided in Art. 11 EMD, which entitles consumers to a dynamic electricity price contract. This entitlement is linked to another set of issues, namely the introduction of intelligent metering systems, commonly known as "smart meters." One obstacle impeding customers from becoming active participants in the energy market and the energy transition has been a lack of transparency regarding real-time or near real-time information about energy consumption. Providing consumers with real-time data and tools - like smart meters - that facilitate participation in the energy market will allow for a transformation from a traditional, centralised and inflexible power grid to a more decentralised, flexible smart grid. Under Art. 19-22 EMD in conjunction with Annex II, makes the introduction of intelligent metering systems by Member States conditional on a positive cost-benefit analysis. If a Member State does not systematically introduce intelligent metering systems, each final customer must still have a right to install such a system, though at their own expense.

Furthermore, Art. 15 EMD requires Member States to ensure that active customers can exercise their rights under Art. 15(1): acting as an active customer may not be subject to disproportionate or discriminatory technical or administrative requirements, procedures and charges, including non-cost-reflective network charges. In addition, under Art. 15(2)(a), active customers have the right to act directly or via aggregators. The storage of self-generated electricity by active customers in their capacity as storage owners is specifically addressed. According to 
Art. 15(5), customers may not be subject to double charges for stored electricity remaining on their land or when providing flexibility services to grid operators.

\section{Prosumer}

Prosumers now play a well-established role in the self-production and feed-in of renewable electricity units. A report drafted by the CE Delft counted nearly 6 million "energy citizens" in the EU and showed that 7 million EU citizens could produce their own electricity by 2030 and over 264 million EU citizens (half its population) by 2050 (Kampman et al., 2016). This development was motivated by profit-yielding remuneration regimes established early on in the Member States' attempts to promote RES. Even though Directive (EC) 2009/72 (the former EMD) did not yet include a definition of "prosumer," it did introduce regulation for smart grids as a prerequisite for a more flexible energy system. Art. 3(5)(11) Directive (EC) 2009/72 states:

In order to promote energy efficiency, Member States or, where a Member State has so provided, the regulatory authority shall strongly recommend that electricity undertakings optimise the use of electricity, for example by providing energy management services, developing innovative pricing formulas or introducing intelligent metering systems or smart grids, where appropriate.

The new EMD contains a legal definition of "prosumer" in Art. 2(8), using the terminology "active customer." Based on this definition, "active customer" means a final customer, or a group of jointly acting final customers, who consumes or stores electricity generated within its premises located within confined boundaries or, where permitted by a Member State, within other premises, or who sells self-generated electricity or participates in flexibility or energy efficiency schemes, provided that those activities do not constitute its primary commercial or professional activity. This definition aligns with the definition of "prosumer" used in the present article.

\section{Self-production}

With Art. 2(8) EMD and Art. 21 RED II, the EU has harmonised and created the right to self-supply and strengthened energy supply concepts. Under Art. 21(2) (a)(ii) RED II, self-generated RE that is used on-site may not be subject to discriminatory or disproportionate procedures or to any kind of levy, allocation or charge, meaning that every Member State must allow self-production.

\section{Self-consumption}

Self-consumption has clear benefits for prosumers, as it is generally cheaper to use self-produced electricity than to obtain electricity over the grid due to electricity 
price components (taxes, levies, charges, etc.). It also has benefits for the energy system and thus for consumers who do not self-consume. By reducing the strain on the grid, it can become a pillar of demand-side management (DSM) and accelerate acceptance of the European energy transition among both businesses and households. Today, self-consumption - the process by which final customers produce and consume their own energy on-site - is a relatively well-established concept in Member States.

The EU formally recognised RE self-consumers and introduced a slightly broader definition of self-consumption in Art. 2(8) EMD and Art. 2(14) RED II. Under the EMD, an "active" customer or self-consumer is entitled to consume, store and sell the electricity that it produces within its premises. Art. 2(14) RED II defines "self-consumption" as generating electricity on-site within specific limits and storing or selling RE generated by an end customer, provided that, in the case of commercial self-suppliers, this is not their main commercial or professional activity. The definitions in both the EMD and the RED II allow Member States to extend self-consumption beyond the premises but exclude professional activities of such kinds.

The definitions differ slightly in terms of the source of electricity, since RE self-consumers are limited to RES. "Active" customers under EMD can also explicitly participate in flexibility or energy efficiency schemes, which are activities beyond energy generation.

With Art. 21 RED II, the EU has standardised the right to self-generation and strengthened self-consumption concepts. Under Art. 21(2)(a)(ii) RED II, selfgenerated RE that remains in place may not be subject to discriminatory or disproportionate procedures or to any kind of levy, allocation or charge. According to Art. 21(3) RED II, exceptions to the exemption from charges and fees for self-supply are possible if

1. the electricity produced by self-generation is effectively supported by a support scheme and the burden does not undermine the economic viability of the project and the incentive effect of the support;

2. from 1 December 2026, if the overall share of (RES) self-consumption installations exceeds $8 \%$ of the total installed electricity generation capacity in a Member State; or

3. the electricity is generated in installations with a total installed capacity of more than 30 kilowatts $(\mathrm{kW})$.

This establishes the general principle that self-consumed electricity remaining behind the meter will not be subject to any charges or fees, although Member States may apply charges in certain limited cases, in particular for installations with a capacity above $30 \mathrm{~kW}$. As a result, Member State legislation prohibiting self-production and self-consumption must be reviewed in light of the EU right to self-consume. 


\section{Marketing flexibility}

Load shifting by prosumers can reduce the total cost of the energy transition. Self-consuming prosumers can relieve the electricity grid, especially if electricity is self-produced and consumed at peak times; the load-shifting process can also help to avoid expensive grid expansion. Furthermore, in the future, selfproduction in combination with battery systems will enable active peak-shaving measures, e.g., the use of electric vehicles. The decline in battery costs is a critical variable for electricity markets as well as for electric cars (IEA, 2019).

Currently, the grid is used unconditionally, i.e., free of conditions, in most cases. This means that the final customer obtains electricity whenever it is needed. Conditional grid usage could motivate grid users to postpone their electricity purchases until a time of day when there is little demand for electricity. For example, users of electric vehicles could be encouraged to charge their vehicles at night rather than directly after work. It is, however, important to ensure that this does not lead to undesirable side effects, such as simultaneity. To this end, grid operators and grid users can enter into written contracts for a certain period of time, and grid users can be offered a financial incentive to shift their load. Art. 3 EMD includes only a very general obligation for the Member States not to "unduly hamper" consumer participation, including through "demand response, investments into, in particular, variable and flexible energy generation, energy storage, or the deployment of electromobility"; it leaves the implementation to the Member States.

\section{Sharing with and sale to third parties and energy cooperatives}

Art. 2(14-15) RED II also introduces the concept of "joint self-supply," which refers to a group of at least two jointly acting self-suppliers located in the same (apartment) building who have essentially the same rights as individual self-suppliers. In particular, they may agree among themselves on the exchange of locally produced RE. The surplus of self-produced electricity can be fed into the grid and virtually forwarded into an energy cloud where a digital electricity account is maintained. This allows the energy surplus to be stored and then withdrawn and consumed when the amount of self-produced electricity is insufficient.

By adopting RED II and EMD, the EU not only broadened the interpretation of self-consumption; it also defined two new electricity market players - in the form of energy communities - that strengthen the participation of citizens in RE production and supply. Art. 22 RED II refers to "renewable energy communities," while Art. 16 EMD uses the term "citizens' energy communities..

Under Art. 22(2) RED II, renewable energy communities have the right to generate, consume, store, sell and share electricity within the citizen energy community. Member States must ensure that renewable energy communities are treated without discrimination regarding their activities (Art. 22(4)(e) RED II). This applies to citizens' energy communities as well, which, according 
to Art. 2(11)(c) EMD, may be active in the areas of production (including RES), distribution, supply, consumption, aggregation, energy storage, energy efficiency services or charging services for electric vehicles; or it may provide other energy services for its members or shareholders.

Although renewable energy communities and citizens' energy communities are, to a large extent, similar, there are minor conceptual differences. Both legal entities are based on open and voluntary participation, controlled by their members or shareholders and primarily intended to provide their members, shareholders or local areas with ecological, economic or social benefits rather than financial profits (Art. 2(11) EMD and Art. 2(16) RED II). As a result, prosumers have a right to group and function in the market collectively.

Furthermore, under Art. 2(16) RED II, renewable energy communities are required to ensure that their shareholders or members are located in close proximity to community projects. The impact of this conceptual difference on practical implementations will become clear only after the directives have been transposed into national laws.

In general, regulations on renewable energy communities and citizens' energy communities contain various undefined legal terms that require more detailed specifications within the legal systems of the Member States. In practice, the suitability of the two legal entities to strengthen citizen participation in electricity generation and distribution will also depend on the concretisation and implementation of European legal requirements.

\section{National frameworks}

The German Energiewende has already led renewables to become the primary source of electricity; RES met $45.4 \%$ of Germany's electricity consumption needs in 2020 (UBA, 2020). Since the passage of the German Renewable Energy Act (Erneuerbare-Energien-Gesetz - EEG) in 2000, households have even had an incentive to produce their own electricity. The costs of RES have also decreased over the years. Germany may meet the obligation prescribed in Directive 2009/28/EC of the European Parliament and of the Council of 23 April 2009 on the promotion of RE use, which requires it to increase the share of RE in gross final energy consumption to at least $18 \%$ by 2020. In 2019, the share of RE in Germany's gross final energy consumption was $17.4 \%$ (Eurostat, 2020).

Poland, on the other hand, has an electricity mix that is unique in Europe due to the highest share of hard coal and brown coal in power and heat production (bpb, 2019). The decarbonisation of power and heat production is nevertheless inevitable. In 2019, renewable energies accounted for 16\% of installed generation capacity (URE, 2020). Still, Poland probably did not meet its obligation under Directive 2009/28/EC to achieve a minimum 15\% share of RE in gross final energy consumption by 2020. In 2019, the share of RE in gross final energy consumption in Poland was 12.2\% (Eurostat, 2020).

Poland and Germany both demonstrate the challenges of the energy transition in the Baltic Sea Region. The following sections provide an overview of the 
status of prosumers in Poland and examine the conditions in Germany in greater depth.

\section{Poland: an overview}

Poland's Energy Policy for 2040 (PEP2040) calls for a significant decrease in the share of coal in the national power generation mix, from the current level of $80 \%$ to $60 \%$ in 2030 and $22 \%$ in 2040 (Ministerstwo Klimatu, 2020). It also contains plans to substantially increase the share of renewable generation in PV capacity and offshore wind; to decrease onshore wind capacity after 2030; and to introduce nuclear power in 2033 (Ministerstwo Klimatu, 2020: 10). In 2030, the share of RES in gross final energy consumption is to be at least 23\% (not less than 32\% in electricity, mainly wind and PV; $28 \%$ in heating (an annual increase of $1.1 \%$ ); and $14 \%$ in transport, with a significant contribution from electromobility) (Ministerstwo Aktywów Państwowych, 2019; Ministerstwo Klimatu, 2020).

As part of PEP2040, a crucial part of the sixth strategic project - implementation of offshore wind energy - is the development of distributed energy generation based on energy production from RES, as well as the sale, storage or participation in demand-side response (DSR) programmes by individual entities (e.g., active consumers, prosumers of renewable energy and others) and energy communities (e.g., energy clusters and energy cooperatives). The Ministerstwo Klimatu expects that the number of prosumers will increase roughly fivefold by 2030, and the number of locally sustainable energy areas will increase to 300 . To safeguard future security of supply, the connection of an unstable energy source will be linked to an obligation to ensure balancing in periods when RES does not supply electricity to the grid. Support mechanisms for RES will give priority to solutions that have maximum availability, entail the lowest relative costs of energy production and meet local energy needs, as well as to hybrid solutions that combine various RES technologies and self-balancing e.g., with the use of energy storage (Ministerstwo Klimatu, 2020).

In Poland, unlike in many other European countries, the majority of PV systems are operated by prosumers. This is because a reduction in technology costs and a favourable regulatory environment (e.g., discounts for prosumers and tax relief for households) have led to a high level of interest among citizens in producing their own energy. In 2015, the Polish Parliament (Sejm) adopted the Renewable Energy Sources Act (Ustawa z dnia 20 lutego 2015 r. o odnawialnych źródłach energii, 2015). This national law introduced a new support scheme for RES based on an auction system. The support is granted through an auction conducted by the President of the Energy Regulatory Office. The Polish government has also implemented a number of measures to support the production of energy from RES. For example, electricity trading power companies are obligated by law to purchase RES energy; RES producers have priority access to the transmission grid; RES electricity is exempt from the excise tax; the grid connection fee for smaller installations $(<5 \mathrm{MW})$ has been reduced by $50 \%$; and investments 
in clean energy may be co-financed by the National Fund for Environmental Protection and Water Management.

In 2019, the installed capacity of PV micro-installations in Poland reached $640 \mathrm{MW}$, reflecting a nearly threefold increase in prosumers year-over-year. PV micro-installations in Poland accounted for over $70 \%$ of the total power installed in PV at the end of 2019. In the first quarter of 2020, about $300 \mathrm{MW}$ of PV microinstallations were installed and connected to the electricity grid (IEO, 2020). The Polish government expects the number of prosumers in the country to reach one million by 2030 .

The increase in prosumption is due to the introduction of a support scheme specifically for RES prosumers, which is based on a special energy supply contract. To benefit from this promotion, a Polish prosumer must sign a complicated, individualised agreement with an energy seller. The seller calculates the difference between the energy produced and the energy consumed. Owners of PV microinstallations (with a capacity of up to $50 \mathrm{~kW}$ ) are allowed to exchange the surplus of energy generated under favourable conditions to make up for shortfalls in their own energy production (Ignaciuk, 2019).

Private energy companies and prosumers thus play the largest role in increasing the share of renewables in the Polish energy mix. These two groups of investors account for a combined $81 \%$ of all renewable capacities installed from 2013-2019. The share of the public sector and state-controlled energy companies in funding renewable energy technologies from 2013-2019 did not exceed 15\% (WiseEuropa, 2020). This indicates that, although coal still accounts for the vast majority of electricity generation in Poland, prosumers already play an important and growing role in renewable energies (especially PV).

\section{Germany: deeper insight}

The following sections offer greater insight into the German legal framework for prosumers.

\section{Flexibility in consumption}

The starting point for the provision of flexibility by consumers in German law is $\S 14 \mathrm{a}$ of the Energy Industry Act (Energiewirtschaftsgesetz - EnWG, 2005). Due to the focus on final consumers in the present analysis, the following discussion does not consider the procurement of balancing power under $\S 12$ (1) EnWG by the four German transmission system operators (TSOs), which are responsible for maintaining grid frequency and supplying balancing power.

$\S 14$ a EnWG is intended to create an incentive for more flexible grid usage by allowing the participation of consumers. The consumer may allow the grid operator or a third party to modulate controllable consumption equipment (e.g., a heat pump or a charging point for electric vehicles) for flexible grid use. In exchange, the consumer is offered a reduced grid fee. The controllable consumption equipment must have a separate metering point. However, 
the scope of application of $\S 14$ a EnWG is limited to the low-voltage range. Larger (commercial) consumption facilities connected to the mediumvoltage level, for example, cannot benefit from the regulation. The Federal Government is authorised, with the consent of the Bundesrat, to specify the obligation in more detail by means of a statutory ordinance ( $\$ 14 \mathrm{a}(3)$ EnWG). The German Federal Ministry for Economic Affairs and Energy (BMWi) has repeatedly postponed the presentation of a draft of a corresponding ordinance (Wiedemann, 2019). At the end of September 2019, the release of the expert report Regulierung, Flexibilisierung und Sektorkopplung (Regulation, flexibilisation and sector coupling) (BET and Boesche, 2018) and the discussion that followed it initiated a broad stakeholder process that was structured under the umbrella of the Working Group on Intelligent Networks and Meters of the Energy Networks Platform. The ongoing process is to be conducted without prejudice to whether and how proposals will be implemented. The BMWi stated: "If necessary, a draft for any necessary legislation will be presented in the course of 2020" (Bundesregierung, 2020: 12). However, soon after presenting a proposed amendment to $\S 14$ a EnWG for revision at the end of 2020, the BMWi withdrew the proposal. The future structure of Section 14a EnWG is therefore still undetermined.

Changes to $\S 14$ a EnWG could further support the integration of new types of flexible consumers (e.g., private charging stations) into distribution grids and avoid inefficient grid expansion at the low-voltage level. Better capacity utilisation of the existing networks is an important prerequisite to ensure that electricity networks do not become a bottleneck in the ramp-up of electromobility.

In principle, variable electricity prices use price signals to create incentives to adapt consumption to the current generation situation. Art. 11 EMD already requires electricity suppliers to offer final consumers load-variable or time-of-daydependent tariffs in order to create an incentive to save energy or to control energy consumption, $\S 40(5)$ EnWG. However, this obligation is conditional on "technical feasibility and economic reasonableness." Such tariffs are not yet widespread due to insufficient installation of the necessary smart technology (Knoll et al., 2020).

\section{Prosumer}

In Germany, there are already regulations in place for prosumers who self-produce electricity and (partly) self-consume, even though the German legal framework does not define prosumers as such.

\section{Self-production}

Electricity production from RES in Germany is mainly supported through a market premium scheme ( $\$ 20$ EEG 2021). For most installations, the award and the level of the market premium a generally determined through a tendering scheme ( 22 EEG); however, feed-in tariffs can also benefit plants with a capacity of up 


\section{Johannes Antoni and Michael Rodi}

to $100 \mathrm{~kW}$ and other plants in exceptional cases, as well as plants that started to produce under previous legal frameworks ( $\$ 21 \mathrm{EEG).}$

Residential prosumers - which often only have small RES plants (most commonly PV up to $100 \mathrm{~kW}$ ) - are therefore generally eligible for feed-in tariffs as prescribed in $\S 19(1)(2)$ and $\S 21 \mathrm{EEG}$. Eligibility is coupled with the obligation of the plant operator to feed the electricity into the grid in the months in which financial support is claimed. Since 2017, the EEG has contained provisions for a tenant electricity surcharge, which supports electricity produced and consumed in the same residential building (§ 21(3) EEG). In addition, all RES plants regardless of size - that feed into the national grid are eligible for a $20 \%$ reduction in the feed-in tariff (Ausfallvergütung) in exceptional cases, although the reduced rate can apply for no longer than three consecutive months and no more than six months within a calendar year $(\S 21(1)(2)$ EEG).

Overall, German law already provides comprehensive support for self-production.

\section{Self-consumption}

After more than a decade of primarily self-producing prosumption in Germany, there has been a shift towards self-consumption due to the decrease in average remuneration for small rooftop PV systems (§ 48(2) EEG) to a level well below the average household electricity price of $€ 0.27$ per kilowatt-hour ( $k W h)$. Selfconsumption allows consumers to lower their electricity bill by using self-produced energy either directly (by meeting their immediate electricity needs) or indirectly (by using batteries and managing their electricity demand). In this way, prosumers can use self-generated electricity for their own supply without marketing it to third parties. In line with the current legal situation in the EEG, selfconsumption concepts are generally charged $40 \%$ of the EEG levy ( $\$ 61 \mathrm{bEEG}$ ). A complete waiver only applies to smaller generation plants with an installed capacity of no more than $10 \mathrm{~kW}$ for no more than 10 megawatt-hours (MWh) of electricity consumed by the producer per calendar year (\$ 61a (4) EEG).

Art. 21(2)(a)(ii)(3) RED II prohibits discriminatory or disproportionate procedures or any kind of levy, allocation or charge for self-generated RE within the premises of the generator. This raises a key question: does charging $40 \%$ of the EEG levy under German law comply with European law, or should this provision be adjusted by the legislature? This is an important question, as it may lead to a need to adapt national regulation to the exemptions for self-supply set out in RED II within the EEG. The new regulation in $\S 61 \mathrm{~b}$ (2) EEG, adopted at the end of 2020, waives the EEG levy for self-consumption up to $30 \mathrm{MWh}$ of electricity per calendar year, as long as production is carried out by an RES plant with an installed capacity of no more than $30 \mathrm{~kW}$. The same applies to conventional energy production plants with a maximum installed capacity of up to $10 \mathrm{~kW}$, as stated in § 61a (4) EEG.

A remaining obstacle to self-supply is the very narrow understanding of the concept of self-consumption in German legislation, specifically the EEG. 
According to its definition in $\S 3(19)$ EEG, self-supply requires the RES plant operator to be the same person as the electricity consumer. As a result, RES plants in multi-party buildings with typical landlord/tenant constellations do not qualify as self-supply; this ultimately forces the tenants to pay the full RES apportionment. Consequently, there are few incentives for tenants to purchase electricity from their own RES plant. From a European law perspective, the definition of self-supply in the German EEG is too narrow. Given the definition of self-supply in Art. 2(14) RED II - which requires end customers to generate electricity on-site within defined limits and to store or sell self-generated RE, provided that this is not their main commercial or professional activity - RES plant operators would be entitled to sell the generated electricity to third parties, as long as this is not their main activity. European law does not require the RES plant operator to be the same person as the electricity consumer. As a result, the landlord/tenant constellation would qualify as self-supply under RED II, but not under the EEG. German legislation is thus contrary to European law and requires action by the legislature.

\section{Marketing flexibility}

Studies show that, in principle, there is technical potential for DSM in all consumption sectors, including industry, trade and commerce and private households (Connect Energy Economics GmbH, 2015; VDE, 2012; Dena, 2010). However, the primary focus so far has been on industry and commerce, since these sectors generally have larger individual loads and professional measuring and control technology is commonly available - important prerequisites to simplify the development of DSM potentials. On the other hand, power-to-X technologies can offer marketable flexibility for sector coupling in which (self-produced) electricity is converted into other energy sources, such as power-to-mobility (electromobility), power-to-gas or power-to-heat (e.g., storage heating or heat applications).

Prosumers can also use battery technologies to store self-produced electricity and thus optimise their external procurement. In addition to personal economic considerations, factors such as technological affinity, self-sufficiency and sustainability aspects also play a major role when private users consider investing in flexibility technologies (Dena, 2017). Active marketing of their flexibility for the energy system is only carried out in isolated cases (ibid.).

The existing regulatory framework in Germany offers flexible grid users (both producers and consumers) few incentives or opportunities to use the grid in a way that aligns with demand and is compatible with the grid status. Like the general energy-related regulatory framework, the existing grid-related regulatory framework is still relatively rigid. Under the current regulatory framework, grid operators do not have sufficiently precise instruments at their disposal to encourage or use flexibility and thus avoid measures like additional grid expansion. In particular, the distribution networks in the low-voltage range are often still a black box for energy suppliers (Wilhelm, 2019). In the future, it will be necessary to be able to monitor the network more closely due to the regulatory disadvantages that, 


\section{Johannes Antoni and Michael Rodi}

among other things, provide a greater incentive to expand the grid than to flexibilise/digitalise grid operation. For this reason, network operators have generally lacked the technical and organisational prerequisites to use existing flexibility in ways that benefit the network.

\section{Sharing with and sale to third parties and energy cooperatives}

Prosumers that actively sell surplus quantities of produced electricity to third parties qualify as energy supply companies under § 3(18) EnWG and § 3(20) EEG. They are thus treated as large companies, regardless of their size. This means that they are subject to the same comprehensive obligations as large energy suppliers, such as notification of the German Federal Network Agency (Bundesnetzagentur) regarding their energy supply in accordance with $\S 5$ EnWG (excluding only supply of household customers exclusively within a customer installation or within a closed distribution network as well as via non-permanent lines ( $(5(1)$ EnWG)). This includes the obligation to immediately notify the TSO regarding the EEG levy in accordance with § 74(1) EEG and report the quantities of electricity supplied in accordance with § 74(2) EEG. In addition, they must comply with legal requirements regarding accounting, contract design and electricity labelling in accordance with $\S$ 40-42 EnWG. If electricity is supplied via the public grid, a grid usage agreement or supplier framework agreement pursuant to $\S 3$ of the Electricity Grid Access Ordinance (Stromnetzzugangsverordnung, 2005) is also required. These bureaucratic obligations significantly challenge prosumers as smaller units and represent a central obstacle to citizen-supported decentralised supply concepts in Germany. Art. 15 EMD regulates the rights of "active" customers, which, according to the definition in Art. 2(8) EMD, also include prosumers. According to these provisions, active customers may not be subject to disproportionate or discriminatory technical or administrative requirements, procedures, levies or charges or to non-cost-oriented network charges. Based on these European legal requirements, it is likely that the German equation of prosumers with energy supply companies is contrary to European law, because it burdens them with disproportionate administrative requirements. As a result, the legislature will need to modify these provisions.

Even though i.e., community-driven energy projects have been part of the German energy landscape since its inception in the early 21st century, there is no real regulation or privileging of energy communities under German law. Currently, German law only regulates Bürgerenergiegesellschaften (citizens' energy communities), which differ from the energy communities at EU level. The scope of application of the Bürgerenergiegesellschaft is limited to tenders for onshore wind energy (§36g EEG). According to § 3(15) EEG, a Bürgerenergiegesellschaft is defined as any company:

(1) Consisting of at least 10 natural persons as members with voting rights or shareholders with voting rights; 
(2) In which at least 51 percent of the voting rights are held by natural persons who have had their registered main residence for at least one year prior to the submission of bids in the city or district in which the wind turbines are to be set up according to the location information in the bid; and

(3) In which no member or shareholder holds more than 10 percent of the voting rights.

It should be noted, however, that German legislation suspended the privileges for Bürgerenergiegesellschaften for two years on 8 June 2018 and ultimately abolished them (Deutscher Bundestag, 2018). This was preceded by a systematic abuse of these privileges due to fears that projects subsidised under the scheme would never be realised.

Therefore, the German legislator must establish renewable/citizens' energy communities and grant them the rights assigned to them by Art. 22 RED II and Art. 16 EMD, respectively. However, due to the rather general provisions of both directives, the legislature has considerable legal scope for implementation. In addition, Art. 22(7) RED II requires Member States to ensure that the support schemes they design for RES allow renewable energy communities to apply under the same conditions as regular RES operators, irrespective of their specific characteristics (Boos, 2019).

\section{Conclusion}

The provisions of the Clean Energy for All Europeans package relating to the activation of people for the energy transition provide an extended framework to democratise access to energy and give everyone the right to participate. This and digitalisation are crucial tools for reaching the goal of decarbonising the economy, diversifying the energy supply and disrupting the traditional balancing of electricity production and demand. Therefore, giving individual rights to self-produce and self-consume and enabling prosumers to establish citizen energy communities represents a significant shift towards greater decentralisation and locally focused politics. Moving away from a few energy companies and their monopolies to more consumer-owned production will offer the possibility for more consumer empowerment.

Regarding the legal framework, it is clear that the rights of prosumers or energy communities granted under EU law remain relatively open to interpretation; the crucial step will be their transposition into national laws. Therefore, each Member State should ensure, among other aspects, that the flexibility of consumers is appropriately addressed in their national frameworks. "Active" consumers, prosumers and energy communities can help to activate the flexibility potential of customers and thus facilitate more effective integration of RES and new technologies, e.g., electric vehicles, into the grid. An effective market design is crucial to ensure that the system is cost-effective overall, not just for those who "actively" participate, because local consumption also needs to respond to effective market price signals. Member States must ensure that self-consumed 
electricity that is used behind the meter is not subject to any charges or fees, although Member States may apply charges in certain limited cases, in particular for installations with a capacity above $30 \mathrm{~kW}$. Models from many other countries show that it is possible to regulate self-consumption in a cost-effective and simple way; one example is the net metering system in Denmark (Wikberg, 2019).

Poland appears to be moving in a promising direction by supporting prosumers with special energy contracts. This development indicates that Poland has implemented effective methods to encourage local citizens to participate in the energy transition. However, it remains to be seen how the further expansion of wind energy, in particular, will proceed. In Germany, EMD and RED II will not bring about significant changes to German law - especially the EEG - regarding active participation. The EEG levy has already been adapted for the self-consumption model. The most significant change will be the establishment of renewable/citizens' energy communities in German law and the granting of rights assigned to them in Art. 22 RED II and Art. 16 EMD.

Granting certain consumer rights to "active" consumers, prosumers or energy communities is only one aspect of improving the balancing of generation and demand. It is also important that active participation in energy communities not entail a (partial) loss of consumer rights, e.g., as a result of supplying or selling energy.

Finally, in order to motivate consumers to become active in the energy transition, e.g., as prosumers, it is crucial to make the process as interesting (e.g., financially attractive), transparent and simple as possible. Adequate and precise information is needed regarding the possibilities to participate in the energy transition. Too often, a lack of important information constitutes a significant obstacle to participation. Sufficient and transparent information, a simple process and the rights of consumers to participate will lead to more flexible demand and grid optimisation. This will also increase acceptance and is essential to the success of the energy transition.

\section{Acknowledgements}

The chapter was written in the context of the Excellence Research Programme "Netz-Stabil" of the federal state of Mecklenburg-Vorpommern, Germany, funded by the European Social Fund (ESF) (funding code ESF/14-BM-A55- 0016/16).

\section{Notes}

1 See the Treaty establishing the Energy Community: www.energy-community.org/legal /treaty.html.

2 See further: https://ec.europa.eu/energy/topics/energy-strategy/clean-energy-all-europeans_en.

\section{References}

BET and Boesche, K. (2018). Gutachten Digitalisierung der Energiewende Topthema 2: Regulierung, Flexibilisierung und Sektorkopplung. Aachen: BET. Available at: www.bmwi 
.de/Redaktion/DE/Publikationen/Studien/digitalisierung-der-energiewende-thema-2 .pdf [Accessed 22 Dec. 2020].

BMWi-energiewende.de (2016). Was ist ein "Prosumer"? Energiewende direct. Available at: www.bmwi-energiewende.de/EWD/Redaktion/Newsletter/2016/06/Meldung/direkt -erklaert.html [Accessed 22 Dec. 2020].

Bons, M., Creutzburg, P. and Schlemme, J. (2020). Energiewende in der Industrie, Potenziale und Wechselwirkungen mit dem Energiesektor, Identifikation neuer Anforderungen aus zukünftigem Strommarktdesign - Flexibilität und Eigenerzeugung, Executive Summary. Berlin: Navigant Energy Germany GmbH, pp. 2-12. Available at: www.bmwi.de/ Redaktion/DE/Downloads/E/energiewende-in-der-industrie-ap2b-executive-summary .pdf [Accessed 22 Dec. 2020].

Boos, P. (2019). Rechtliche Stellungnahme, Europäische Förderung von kollektiver Eigenversorgung und Emeuerbare-Energie-Gemeinschaften. Berlin: BH\&W - Boos Hummel \& Wegerich. Available at: www.buendnis-buergerenergie.de/fileadmin /user_upload/2019-08-22_BHW-BBEn_Europaeische_Foerderung_kollektive_ Eigenversorgung_EE-Gemeinschaften_durchsuchbar_pdf [Accessed 22 Dec. 2020].

$\mathrm{bpb}$ - Bundeszentrale für politische Bildung (2019). Energiemix nach Staaten. Bundeszentrale für politische Bildung. Available at: https://www.bpb.de/nachschlagen /zahlen-und-fakten/europa/75140/themengrafikenergiemix-nach-staaten [Accessed 22 Dec. 2020].

Bundesnetzagentur (2016). Begriffe - Prosumer. Bundesnetzagentur. Available at: www .bundesnetzagentur.de/DE/Sachgebiete/ElektrizitaetundGas/Verbraucher/Netzanschlu ssUndMessung/Metering/faq_Begriffe_table.html\#FAQ697820 [Accessed 22 Dec. 2020].

Bundesregierung (2016). Gesetzentwurf zur Digitalisierung der Energiewende. Berlin: Deutscher Bundestag, BT-Drs. 18/7555, pp. 1, 62, 107-9. Available at: http://dip21 .bundestag.de/dip21/btd/18/075/1807555.pdf [Accessed 22 Dec. 2020].

Bundesregierung (2020). Antwort auf die kleine Anfrage (Drucksache 19/15802) der Abgeordneten Sandra Weeser, Michael Theurer, Reinhard Houben, weiterer Abgeordneter und der Fraktion der FDP. Berlin: Deutscher Bundestag, BT-Drs 19/16417. Available at: http://dip21.bundestag.de/dip21/btd/19/164/1916417.pdf [Accessed 22 Dec. 2020].

Cai, Y., Huang, T., Bompard, E., Cao, Y. and Li, Y. (2016). Self-sustainable community of electricity prosumers in the emerging distribution system. IEEE Transactions on Smart Grid, 8(5), New York: IEEE, pp. 2207-216. Available at: https://ieeexplore.ieee.org/ document/7395372. [Accessed 22 Dec. 2020].

Connect Energy Economics GmbH (2015). Leitstudie Strommarkt 2015. Berlin: Connect Energy Economics GmbH. Available at: www.bmwi.de/Redaktion/DE/Publikationen/ Studien/leitstudie-strommarkt-2015.pdf [Accessed 22 Dec. 2020].

Dena (2010). Dena-Netzstudie II. Integration erneuerbarer Energien in die deutsche Stromversorgung im Zeitraum 2015 - 2020 mit Ausblick 2025. Berlin: dena, pp. 46675. Available at: www.dena.de/fileadmin/dena/Dokumente/Pdf/9106_Studie_dena -Netzstudie_II_deutsch.PDF [Accessed 22 Dec. 2020].

Dena (2017). Dena-Netzflexstudie, Optimierter Einsatz von Speichern für Netz- und Marktanwendungen in der Stromversorgung. Berlin: dena, pp. XXI-XXVI. Available at: www.dena.de/fileadmin/dena/Dokumente/Pdf/9191_dena_Netzflexstudie.pdf [Accessed 22 Dec. 2020].

Dernbach, B. (2015). Energiewende - ein politisch besetzter Begriff. Jahrbuch für Christliche Sozialwissenschaften (JCSW), 56, pp. 23-35. Available at: www.uni-muenster.de/ Ejournals/index.php/jcsw/article/download/1540/1442 [Accessed 22 Dec. 2020]. 
Deutscher Bundestag (2018). Drittes Gesetz zur Änderung des Erneuerbare-EnergienGesetz, vom 21. Juni 2018. Berlin: Deutscher Bundestag, BT-Drs. 19/1320. Available at: http://dipbt.bundestag.de/extrakt/ba/WP19/2308/230856.html [Accessed 22 Dec. 2020].

EEG (2021). (Renewable Energies Act). 21 July 2014. Federal Law Gazette I p. 1066, last amended by Article 1 of the Act of 21 December 2020 (Federal Law Gazette I p. 3138). Available at: www.gesetze-im-internet.de/eeg_2014/EEG_2021.pdf [Accessed 22 Dec. 2020].

Energiewirtschaftsgesetz (2005). (Energy Industry Act). 7 July 2005, Federal Law Gazette I p. 1970, 3621 last amended by Art. 2 of the Act of 21 December 2020 (Federal Law Gazette I p. 3138). Available at: www.gesetze-im-internet.de/enwg_2005/EnWG.pdf [Accessed 22 Dec. 2020].

EPRS - European Parliamentary Research Service (2016). Briefing November 2016, Electricity 'Prosumers', ENPE 593.518. Available at: www.europarl.europa.eu/RegData /etudes/BRIE/2016/593518/EPRS_BRI(2016)593518_EN.pdf [Accessed 22 Dec. 2020].

European Commission (2019). Report to The European Parliament, The Council, The European Economic and Social Committee and the Committee of the Regions: Renewable Energy Progress Report. Brussels: European Commission, 9. April 2019, COM(2019) 225 final.

European Council (2014). European Council (23 and 24 October 2014) - Conclusions. Brussels: European Council, 24. October 2014, EUCO 169/14.

Eurostat (2020). Share of Renewable Energy in Gross Final Energy Consumption. December 2020. eurostat. Available at: https://ec.europa.eu/eurostat/databrowser/view/t2020_31/ default/table [Accessed 22 Dec. 2020].

IEA - International Energy Agency (2019). World Energy Outlook 2019, Executive Summary. Paris: IEA. Available at: https://iea.blob.core.windows.net/assets/1f6bf453 -3317-4799-ae7b-9cc6429c81d8/English-WEO-2019-ES.pdf [Accessed 22 Dec. 2020].

IEO - Instytut Energetyki Odnawialnej (Institute for Renewable Energy) (2020). PV Market in Poland 2020. 8th edition. Warsaw: IEO. Available at: https://ieo.pl/en/pv -report [Accessed 22 Dec. 2020].

Ignaciuk, K. (2019). Promotion in Poland. Legal Sources on Renewable Energy. Available at: www.res-legal.eu/search-by-country/poland/tools-list/c/poland/s/res-e/t/promotion/ sum/176/lpid/175/ [Accessed 22 Dec. 2020].

Kampman, B., Blommerde, J. and Afman, M. (2016). The Potential of Energy Citizens in the European Union. Delft: CE Delft, Available at: https://ce.nl/wp-content/uploads/2021 103/CE_Delft_3J00_Potential_energy_citizens_EU_final_1479221398.pdf [Accessed 22 Dec. 2020].

Knoll, F., Witting, A. and Antoni, J. (2020). Das Smart Grid - Eine neue Infrastruktur und deren Beitrag zur stabilen Stromversorgung. REthinking: Law, 05, Düsseldorf: Fachmedien Otto Schmidt, pp. 47-51.

Leal-Arcas, R., Lesniewska, F. and Proedrou, F. (2018). Prosumers as new energy actors, Chapter 12. In: Africa-EU Renewable Energy Research an Innovation Symposium 2018 (RERIS 2018). Cham: Springer, pp. 139-51. DOI:10.1007/978-3-319-93438-9_12.

Milovanović, V. (2019). § 55 MsbG, Messwerterhebung Strom. In: Danner/Theobald, ed., Energierecht, 103. EL Berlin: C.H.Beck, Rn. 16.

Ministerstwo Aktywów Państwowych (Ministry of State Assets). (2019). National Energy and Climate Plan for 2021-2030, Objectives and Targets, and Policies and Measures (NECP Poland). Warsaw: Ministerstwo Aktywów Państwowych. Available at: https:// 
ec.europa.eu/energy/sites/ener/files/documents/pl_final_necp_part_1_3_en.pdf [Accessed 22 Dec. 2020].

Ministerstwo Klimatu (Ministry of Climate). (2020). Polityka energetyczna Polski do 2040 r. September 2020. Warsaw: Ministerstwo Klimatu. Available at: https://www.gov .pl/attachment/114c135e-bd7e-4152-8666-d3f64a53765b [Accessed 22 Dec. 2020].

Müller-Kirchenbauer, J. and Leprich, U. (2013). Anforderungen an leistungsfähige Verteilnetze im Rahmen der Energiewende, Zeitschrift für das gesamte Recht der Energiewirtschaft (EnWZ). Munich: C.H BECK, pp. 101-6.

Pause, F. and Kahles, M. (2019). Die finalen Rechtsakte des EU-Winterpakets "Saubere Energie für alle Europäer" - Teil 2 - EU-Strombinnenmarkt. EnergieRecht (ER), Berlin: Erich Schmidt Verlag, pp. 47-52.

Pielow, J.-C. (2010). Effektives Recht der Energieeffizienz? Zeitschrift für Umweltrecht (ZUR), Heft 3, Baden-Baden: Nomos, pp. 115-23.

Roberts, J. (2016). Prosumer Rights: Options for a Legal Framework Post-2020. London: ClientEarth, pp. 7-10. Available at: www.documents.clientearth.org/wp-content/ uploads/library/2016-06-03-prosumer-rights-options-for-an-eu-legal-framework-post -2020-coll-en.pdf [Accessed 22 Dec. 2020].

Roberts, J., Bodman, F. and Rybski, R. (2014). Community Power: Model Legal Frameworks for Citizen-owned Renewable Energy. London: ClientEarth. Available at: https://www .communitypower.eu/images/Clientearth_report.pdf [Accessed 22 Dec. 2020].

Schäfer-Stradowsky, S. and Timmermann, D. (2018). Verschiebung von Kompetenzen zwischen ÜNB und VNB durch die Digitalisierung der Energiewende. Zeitschrift für das gesamte Recht der Energiewirtschaft (EnWZ), Munich: C.H BECK, pp. 199-207.

Stromnetzzugangsverordnung (2005). (Regulation on access to electricity supply networks). Federal Law Gazette I p. 2243, last amended by Article 3 of the Act of 21. December 2020 (Federal Law Gazette I p. 3138). Available at: www.gesetze-im -internet.de/stromnzv/StromNZV.pdf [Accessed 22 Dec. 2020].

UBA - Umweltbundesamt (2020). Renewable Energies in Figures. Available at: www .umweltbundesamt.de/en/topics/climate-energy/renewable-energies/renewable -energies-in-figures [Accessed 22 Dec. 2020].

URE-Urząd Regulacji Energetyki (Energy Regulatory Office) (2020). 2019 Electricity Market Characteristics. Available at: www.ure.gov.pl/en/markets/electricity/elctricitymrket/292 ,2019-Electricity-Market-Characteristics.html [Accessed 22 Dec. 2020].

Ustawa z dnia 20 lutego 2015 r. o odnawialnych źródłach energii (2015), Law on Renewable Energy Sources. Available at: www.ure.gov.pl/pl/urzad/prawo/ustawy/6092,Ustawa-zdnia-20-lutego-2015-r-o-odnawialnych-zrodlach-energii.html [Accessed 22 Dec. 2020].

VDE (2012). VDE-Studie: Demand Side Integration - Lastverschiebepotenziale in Deutschland. VDE. Available at: www.vde.com/de/etg/publikationen/studien/etg-vde -studie-lastverschiebungspotenziale [Accessed 22 Dec. 2020].

Wiedemann, K. (2019). Smart Meter, Wirtschaftsministerium organisiert Digitalisierung der Energiewende neu. Energate messenger, 27. August 2019. Available at: www.energate -messenger.de/news/194615/wirtschaftsministerium-organisiert-digitalisierung-der -energiewende-neu [Accessed 22 Dec. 2020].

Wikberg, K. (2019). Net-Metering. Legal Sources on Renewable Energy. Available at: www .res-legal.eu/search-by-country/denmark/single/s/res-e/t/promotion/aid/net-metering/ lastp/96/ [Accessed 22 Dec. 2020].

Wilhelm, F. (2019). Licht in die Blackbox. Energie Eु Management, 1. July 2019, pp. 1011. Available at: www.bet-energie.de/fileadmin/redaktion/PDF/Veroeffentlichungen /2019/E_M-Licht.in.die.Blackbox.pdf [Accessed 22 Dec. 2020]. 


\section{Johannes Antoni and Michael Rodi}

WiseEuropa - Warsaw Institute for Economic and European Studies (2020). Alternating Current, Landscape of Climate Finance in the Polish Energy Sector. Warzsaw: WiseEuropa, pp. 22-24. Available at: https://wise-europa.eu/wp-content/uploads/2020/07/Alternating _Current_pdf [Accessed 22 Dec. 2020].

Wübbels, M. (2015). Verteilnetze als tragende Säule der Energiewende. Zeitschrift für das gesamte Recht der Energiewirtschaft (EnWZ), Munich: C.H BECK, pp. 193-4. 